\title{
KONSEP OBJEKTIVITAS DALAM PEMBUATAN \\ LAPORAN KEUANGAN (STUDI KASUS PADA HOME INDUSTRY UD. AR. \\ PUTRA TAHUN 2016-2017)
}

\author{
Dion Yanuarmawan \\ Politeknik Kediri \\ dionpoltekkediri@gmail.com
}

\begin{abstract}
The basic concept of accounting is a variety of concepts that can be standardized in delivering a neat and easy to understand financial statements. The basic concept of accounting is the concept of business entity and cost concept. The concept of cost determines that the property or services obtained must be recorded on the basis of actual costs, and the concept of cost itself is divided into two, namely the concept of measurement units and the concept of objectivity.

This type of research is quantitative, used to study in depth about the application of basic concept of objectivity in recording financial statements in UD. AR PUTRA. Secondary data source used is transaction proof data at UD. AR PUTRA which covers the amount of purchase requirement during 2017 and sales data. Population in this research is financial report at UD. AR. PUTRA year 2017. The sample in this research is income statement of Year 2017 at UD. AR PUTRA.

The results of the study obtained the details of the needs of $2017 R p$ 85,888,333, sales details of 2017 Rp766.647.000, trial balance $2017 R p$ 1,162,025,600, total general journal $R p$ 90.231.200, adjusting journal $R p$ 17.196.667.
\end{abstract}

Keyword: Basic Concepts of Accounting, Financial Statements, Objectivity

\section{PENDAHULUAN}

Konsep dasar akuntansi merupakan suatu konsep yang berlaku secara umum tentang suatu asumsi, anggapan, pandangan maupun pendapat dalam menyajikan informasi keuangan kepada pihakpihak yang berkepentingan. Konsepkonsep akuntansi yang digunakan dalam lingkungannya akan sangat dipengaruhi oleh pengetahuan, pengalaman, kondisi sosial, kondisi ekonomi, politik dan sebagainya. Konsep dasar akuntansi ada dua yaitu pertama, entitas bisnis yang dimaksud adalah dalam membuat laporan keuangan tidak boleh dijadikan satu, misalnya dua perusahaan harus disendirikan untuk laporan keuangannya jadi setiap perusahaan memiliki laporan keuangan sendiri. Kedua, konsep biaya artinya segala transaksi 
harganya sesuai harga perolehan, konsep biaya ini dibagi menjadi dua konsep yaitu konsep objektivitas dan konsep unit pengukuran. Konsep objektivitas merupakan segala transaksi harus ada buktinya, bisa mengandung arti bahwa dalam pembuatan sebuah laporan keuangan serta catatan akuntansi maka sumber data yang digunakan harus dapat diverifikasi atau diperiksa kebenarannya, sedangkan konsep unit pengukuran artinya laporan keuangan harus dapat diukur dengan cara mengukurnya harus ada angka dengan menggunakan mata uang.

Laporan keuangan adalah informasi keuangan suatu perusahaan pada suatu periode akuntansi yang dapat digunakan untuk menggambarkan kinerja perusahaan tersebut. Laporan keuangan yang lengkap biasanya meliputi neraca, laporan laba rugi komprehensif, laporan perubahan ekuitas, laporan arus kas, catatan atas laporan keuangan. Neraca atau laporan posisi keuangan adalah bagian dari laporan keuangan suatu entitas yang dihasilkan pada suatu periode akuntansi yang menunjukan posisi keuangan entitas tersebut pada akhir periode, neraca terdiri dari tiga unsur yaitu aset, liabilitas, dan ekuitas. Aset adalah sumber ekonomi yang diharapkan memberikan manfaat usaha di kemudian hari, aset pencatatannya dalam neraca dengan saldo normal debit, sedangkan liabilitas merupakan hutang yang harus dilunasi pada masa yang akan datang kepada pihak lain. Liabilitas kebalikan dari aset yang merupakan sesuatu yang dimiliki, contoh liabilitas adalah uang dipinjam dari pihak lain, giro atau cek yang belum dibayarkan, dan pajak penjualan yang belum dibayarkan ke negara. Ekuitas atau nilai nominal awal pembukaan dalam suatu perusahaan, biasa disebut dengan modal.

Laporan laba rugi bagian dari laporan keuangan suatu perusahaan dihasilkan dari suatu periode akuntansi yang menjabarkan unsurunsur pendapatan dan beban perusahaan sehingga menghasilkan laba atau rugi bersih. Laporan perubahan ekuitas salah satu dari laporan keuangan yang harus dibuat oleh perusahaan di mana menggambarkan peningkatan dan penurunan aktiva bersih atau 
kekayaan selama periode yang bersangkutan berdasarkan prinsip tertentu yang dianut. Laporan arus kas bagian dari laporan keuangan suatu perusahaan dihasilkan dari suatu periode akuntansi yang menunjukkan aliran masuk dan keluaran uang kas perusahaan. Catatan laporan keuangan merupakan informasi yang ditambahkan ke akhir laporan keuangan untuk memberikan tambahan informasi kepada pembaca dengan lebih lanjut.

Home Industry UD. AR. PUTRA dalam pencatatan keuangannya masih menggunakan yang manual. Pembelian bahan baku penjualan produk masih menggunakan nota saja belum mencatat dalam laporan keuangan. Perlu dilaksanakan pencatatan laporan keuangan, maka dilakukan analisis konsep

objektivitas sebagai salah satu pilihan perbandingan antara kebijakan yang telah dilaksanakan.

\section{KAJIAN TEORI}

\subsection{Pengertian Konsep Dasar Akuntansi}

Konsep dasar akuntansi merupakan suatu konsep yang berlaku secara umum tentang suatu asumsi, anggapan, pandangan maupun pendapat dalam menyajikan informasi keuangan kepada pihak-pihak yang berkepentingan. Konsep dasar akuntansi antara lain yaitu :

1. Konsep entitas bertujuan agar transaksi perusahaan tidak boleh digabung dengan transaksi pribadi atau transaksi lainnya. Konsep kesatuan usaha menyatakan bahwa akuntansi yang berlaku untuk suatu unit ekonomi tertentu tidak boleh dicampuradukkan dengan unit ekonomi lainnya.

2. Konsep biaya merupakan konsep yang terpenting dalam akuntansi manajemen dan akuntansi biaya. Tujuan memperoleh informasi biaya digunakan untuk proses perencanaan, pengendalian dan pembuatan keputusan. Tujuan lain mengapa harus memahami konsep dan definisi biaya 
karena ada beberapa istilah yang menyerupai biaya dalam konteks cost, ada pula beban (expenses) dan kerugian (loss), keduanya juga merupakan pengorbanan sumber ekonomi namun untuk lebih jelasnya dipilah kembali bahwa beban (expenses) adalah bagian dari cost sedangkan kerugian (loss) adalah pengorbanan sumber daya namun tidak menghasilkan pendapatan atau tidak mencapai tujuan yang ingin dicapai organisasi perusahaan. Konsep biaya ini dibagi menjadi dua konsep yaitu konsep objektivitas dan konsep unit pengukuran.

\section{a. Konsep Objektivitas}

Objektivitas bukti harus dievaluasi atas dasar kondisi yang melingkupi penciptaan, pengukuran dan penangkapan atau pengakuan data akuntansi. Objektivitas bisa mengandung arti bahwa dalam pembuatan sebuah laporan keuangan atau laporan serta catatan akuntansi maka sumber data yang digunakan harus dapat diverifikasi atau diperiksa kebenarannya, apabila buktibukti transaksi yang digunakan sebagai sumber tidak objektif maka tentu saja laporan dan catatan akuntansi yang dihasilkan menjadi tidak objektif dan tidak sesuai. Akuntansi tidak mendasarkan diri pada objektivitas mutlak melainkan pada objektivitas relatif yaitu objektivitas yang paling tinggi pada waktu transaksi terjadi dengan mempertimbangkan keadaan dan tersedianya informasi pada waktu tersebut.

b. Konsep Unit Pengukuran Pengukuran adalah penentuan besaran, dimensi, atau kapasitas, biasanya terhadap suatu standar atau satuan pengukuran. Pengukuran tidak hanya terbatas pada kuantitas fisik, tetapi juga dapat diperluas untuk mengukur hampir semua benda yang bisa dibayangkan, seperti tingkat ketidakpastian, atau kepercayaan konsumen. Pengukuran adalah proses pemberian angka-angka atau 
label kepada unit analisis untuk merepresentasikan atribut-atribut konsep. Proses ini seharusnya cukup dimengerti orang walau misalnya definisinya tidak dimengerti. Hal ini karena antara lain kita sering kali melakukan pengukuran (Resti,2017).

\subsection{Definisi Laporan Keuangan}

Laporan keuangan merupakan alat penguji dari pekerjaan bagian pembukuan yang digunakan untuk menentukan atau menilai posisi keuangan perusahaan. Laporan keuangan dapat diketahui posisi keuangan perusahaan serta hasil-hasil yang telah dicapai perusahaan. Laporan keuangan juga merupakan summary proses perhitungan setiap tutup pembukuan yang digunakan untuk melihat perkembangan perusahaan. Laporan keuangan adalah laporan tertulis yang memberikan informasi kuantitatif tentang posisi keuangan dan perubahan-perubahannya, serta hasil yang dicapai selama periode tertentu. Posisi keuangan memberikan gambaran tentang bagaimana susunan kekayaan yang dimiliki perusahaan dan sumber- sumber kekayaan itu diperoleh. Perubahan posisi keuangan menunjukkan kemajuan perusahaan, memberikan gambaran tentang apakah perusahaan memperoleh laba dalam melaksanakan kegiatannya, dan apakah perusahaan mengalami perkembangan yang menunjukan manajemen telah mengelola perusahaan dengan berhasil (Resti, 2017).

\subsection{Karakteristik dan Kegunaan \\ Laporan Keuangan}

Karakteristik laporan keuangan perusahaan (Resti, 2017) adalah:

1. Dapat dipahami oleh pemakai informasi mengenai laporan keuangan perusahaan.

2. Relevan, yaitu adanya kesesuaian antara pemasukan dan pengeluaran perusahaan untuk periode tertentu sebagaimana yang tertuang pada laporan.

3. Netralitas, yaitu semua yang diinformasikan harus diarahkan pada kebutuhan umum pemakai bukan tunduk pada pesan sponsor.

4. Dapat dibandingkan, yaitu membandingkan laporan keuangan perusahaan antar periode untuk mengidentifikasi kecenderungan (trend) posisi dan kinerja keuangan. 


\subsection{Jenis Laporan Keuangan}

Jenis laporan keuangan (Resti, 2017) adalah sebagai berikut:

1. Laporan laba rugi merupakan suatu ikhtisar yang menggambarkan total pendapatan dan total biaya, serta laba yang diperoleh perusahaan dalam suatu periode akuntansi tertentu.

2. Laporan perubahan modal merupakan ikhtisar yang menunjukkan perubahan modal dari awal periode akuntansi menjadi saldo modal akhir tahun setelah ditambah dengan laba tahun berjalan dan dikurangi dengan pembagian laba seperti prive dalam perusahaan perorangan atau deviden dalam perusahaan yang berbentuk perseroan terbatas.

3. Neraca atau laporan posisi keuangan merupakan suatu laporan yang menggambarkan posisi keuangan perusahaan pada suatu saat tertentu yang terdiri dari aktiva, kewajiban, dan ekuitas.

4. Laporan arus kas menunjukkan saldo kas akhir perusahaan yang dirinci atas arus kas bersih dari aktivitas operasi, arus kas berasal dari aktivitas investasi, serta arus kas bersih dari aktivitas pendanaan.
5. Catatan atas laporan keuangan yang lengkap biasanya memuat catatan atas laporan keuangan yang menjelaskan tentang gambaran umum perusahaan, serta penjelasan atas pos-pos signifikan dari laporan keuangan perusahaan.

\section{HASIL ANALISIS DAN PEMBAHASAN}

\subsection{Profil UD AR. PUTRA}

UD AR PUTRA adalah usaha mikro kecil menengah yang bergerak di bidang manufaktur yang memproduksi coklat yang terletak di Dsn. Payak, Ds. Tanon, Kec. Papar Kediri. UD AR PUTRA didirikan pada tahun 2013 oleh Bapak Edi Prastowo. Coklat digunakan sebagai camilan atau teman pada saat berkumpul bersama teman-teman. Pemilik awalnya mengembangkan hasil dari pekerjaan sebagai salah satu perangkat di desa dan melihat peluang bisnis yang cukup bagus untuk mendirikan usaha memproduksi coklat karena pada waktu itu di wilayah Kabupaten Kediri masih jarang ditemukan usaha yang memproduksi coklat. Pemilik memiliki kemampuan usaha dalam memproduksi coklat yang 
diperoleh dari pengalaman

marketing pemasaran snack. Awal pendirian pemilik bermodalkan dari banyaknya relasi dan kepercayaan yang digunakan untuk membeli mesin, peralatan dan perlengkapan yang mendukung dalam proses produksi pembuatan coklat. UD AR PUTRA dalam awal pendiriannya memiliki 5 karyawan dalam proses produksi coklat.

Pendirian usaha UD AR PUTRA awalnya belum terlalu dikenal masyarakat karena kurang luasnya cakupan daerah pemasaran serta promosi yang masih terbatas, sehingga Bapak Edi Prastowo juga menambah cakupan daerah pemasaran dengan harapan agar usahanya lebih dikenal oleh masyarakat baik di Kecamatan Papar dan sekitarnya. UD AR PUTRA mulai dikenal masyarakat luas dan permintaan coklat pun meningkat seiring berjalannya waktu. Melihat semakin banyaknya permintaan coklat dan Bapak Edi Prastowo merekrut 7 karyawan baru antara lain tetangganya sendiri.

Coklat yang diproduksi pada UD AR PUTRA hanya satu bentuk yaitu dengan bentuk kotak-kotak. Pemilik selalu terjun langsung untuk mengontrol para karyawannya dalam proses produksi, dan Bapak Edi Prastowo juga ikut membantu para karyawannya dalam proses produksi. Bapak Edi Prastowo yang menginginkan usaha ini semakin berkembang dan dikenal oleh masyarakat maka selalu menjaga kualitas produk dan selalu memperbaiki produk. Setiap tahun Bapak Edi Prastowo selalu menambah karyawan untuk meningkatkan produksi guna untuk memenuhi permintaan coklat. UD. AR PUTRA dalam proses produksinya memiliki struktur organisasi garis. Bapak Edi Prastowo sebagai pemilik dan pemimpin di UD. AR PUTRA memiliki kewenangan untuk memerintah langsung bawahan dan bawahan mempunyai tanggungjawab kepada atasan.

\subsection{Uraian Tugas}

Pembagian tugas dan tanggung jawab pada UD. AR PUTRA dibagi menurut fungsi yang telah ditetapkan. Tugas dan tanggung jawab setiap bagian dalam perusahaan adalah sebagai berikut: 
1. Pemilik

Pemilik merupakan pimpinan tertinggi dalam perusahaan yang memiliki keseluruhan modal selama proses produksi berlangsung. Tugas pemilik adalah mengawasi jalannya proses produksi dan kinerja dari operator.

Tanggung jawab pemilik adalah sebagai berikut:

a. Memberikan upah dan memperhatikan kesejahteraan operator yang bekerja.

b. Memelihara dan mempertahankan mutu dari tiap-tiap pelaksanaan tugas, efektifitas pabrik dan penggunaan tiap daya secara produktif.

c. Mengurus dan berusaha agar semua kekayaan dan semua fasilitas perusahaan dijaga sebagaimana mestinya.

2. Bagian Pembuat Adonan

Tugas bagian pembuat adonan adalah membuat adonan coklat yang dipanaskan dengan wafer yang sudah dihancurkan tercampur dengan halus agar dapat segera di cetak.

3. Bagian Pencetakan

Tugas dari bagian pencetakan adalah mencetak coklat dalam wadah persegi dan meletakkan hasil cetakan keatas ebek.

4. Bagian Pembekuan

Tugas bagian pembekuan memasukan hasil cetakan coklat dalam freazer.

5. Bagian Pengemasan

Bagian pengemasan merupakan tahap akhir dari proses pembuatan coklat. Tugas bagian pembungkusan adalah membungkus coklat untuk siap diangkut dan dipasarkan ke tempat-tempat makan dan toko.

6. Bagian Pengiriman

Bagian pengiriman merupakan bagian yang bertugas mengantar produk coklat yang sudah di kemas ke tempat-tempat makan dan toko dalam dan luar kota.

7. Bagian Pembukuan

Tugas bagian pembukuan adalah mencatat pembelian bahan-bahan yang diperlukan dalam proses produksi dan mencatat penjualan produksi.

\subsection{Hasil Penelitian}

Konsep dasar akuntansi merupakan berbagai konsep yang dapat dijadikan standar dalam menyampaikan laporan keuangan yang rapi dan mudah dipahami. Pembuatan laporan keuangan harus 
didasarkan pada 2 konsep dasar akuntansi yaitu konsep entitas usaha dan konsep biaya. Konsep biaya menetapkan bahwa harta atau jasa yang diperoleh harus dicatat atas dasar biaya yang sesungguhnya, dan konsep biaya itu sendiri dibagi menjadi 2 yaitu konsep unit pengukuran dan konsep objektivitas. UD. AR PUTRA belum menerapkan adanya konsep objektivitas dalam pembuatan laporan keuangan. Laporan keuangan pada UD. AR Putra masih sangat sederhana, dan tidak menggunakan standar apapun dalam pembuatannya.

Peneliti menggunakan sumber data primer dan data sekunder, akan tetapi penelitian ini lebih menitikberatkan pada data sekunder. Data sekunder dalam penelitian ini adalah laporan keuangan UD. AR PUTRA periode tahun 2016 dan 2017 pembukuan kebutuhan dan penjualan, neraca saldo, transaksi, jurnal umum, dan buku besar. model regresi ini telah terdistribusi.

Tabel 1. Rincian Kebutuhan UD. AR PUTRA Tahun 2016

\begin{tabular}{|c|c|c|}
\hline Nama Kebutuhan & Nominal & Presentase \\
\hline Kertas Mas & $\begin{array}{ll}\mathrm{Rp} & 200.000\end{array}$ & $0,290 \%$ \\
\hline Kardus & 150.000 & $0,217 \%$ \\
\hline Roti & $\mathrm{Rp} \quad 12.200 .000$ & $17,709 \%$ \\
\hline Coklat Batang & $\mathrm{Rp} \quad 20.500 .000$ & $29,757 \%$ \\
\hline Mangkok & $\begin{array}{ll}\mathrm{Rp} & 14.000 .000 \\
\end{array}$ & $20,322 \%$ \\
\hline Solasi & $\begin{array}{ll}\mathrm{Rp} & 250.000 \\
\end{array}$ & $0,362 \%$ \\
\hline Label & 300.000 & $0,435 \%$ \\
\hline Stiker & 100.000 & $0,145 \%$ \\
\hline Plastik & $\begin{array}{ll}\mathrm{Rp} & 400.000\end{array}$ & $0,580 \%$ \\
\hline Gas & Rp 10.000 .000 & $14,515 \%$ \\
\hline Gaji Karyawan & Rp $\quad 5.000 .000$ & $7,257 \%$ \\
\hline Listrik & 90.000 & $0,130 \%$ \\
\hline Kardus Karton & $\begin{array}{ll}\mathrm{Rp} & 700.000 \\
\end{array}$ & $1,016 \%$ \\
\hline Total & Rp 68.890.000 & \\
\hline
\end{tabular}

Sumber: UD AR PUTRA Tahun 2018 
Berdasarkan tabel di atas diketahui rincian kebutuhan pada tahun 2016, pembelian tertinggi terdapat pada biaya coklat batang yaitu sebesar Rp 20.500.000 biaya terendah terdapat pada biaya lisrik sebesar Rp 90.000 . Presentase diperoleh dari hasil pembagian antara total per akun dengan total keseluruhan lalu dikali $100 \%$.

Tabel 2. Rincian Kebutuhan UD. AR PUTRA Tahun 2017

\begin{tabular}{|l|cr|c|}
\hline \multicolumn{1}{|c|}{ Nama Kebutuhan } & \multicolumn{2}{|c|}{ Nominal } & Presentase \\
\hline Kertas Mas & $\mathrm{Rp}$ & 500.000 & $0,852 \%$ \\
\hline Kardus & $\mathrm{Rp}$ & 300.000 & $0,349 \%$ \\
\hline Roti & $\mathrm{Rp}$ & 15.200 .000 & $17,697 \%$ \\
\hline Coklat Batang & $\mathrm{Rp}$ & 30.800 .000 & $35,860 \%$ \\
\hline Mangkok & $\mathrm{Rp}$ & 16.120 .000 & $18,768 \%$ \\
\hline Solasi & $\mathrm{Rp}$ & 450.000 & $0,523 \%$ \\
\hline Label & $\mathrm{Rp}$ & 500.000 & $0,582 \%$ \\
\hline Stiker & $\mathrm{Rp}$ & 200.000 & $0,232 \%$ \\
\hline Plastik & $\mathrm{Rp}$ & 535.000 & $0,622 \%$ \\
\hline Gas & $\mathrm{Rp}$ & 11.000 .000 & $12,807 \%$ \\
\hline Gaji Karyawan & $\mathrm{Rp}$ & 9.200 .000 & $10,711 \%$ \\
\hline Listrik & $\mathrm{Rp}$ & 183.333 & $0,213 \%$ \\
\hline Kardus Karton & $\mathrm{Rp}$ & 900.000 & $1,047 \%$ \\
\hline Total & $\mathrm{Rp}$ & $\mathbf{8 5 . 8 8 8 . 3 3 3}$ & \\
\hline
\end{tabular}

Sumber: UD. AR PUTRA tahun 2018

Berdasarkan tabel di atas diketahui rincian kebutuhan pada tahun 2017, kebutuhan tertinggi terdapat pada biaya coklat batang yaitu sebesar Rp 30.800.000 kebutuhan terendah terdapat pada biaya lisrik sebesar Rp 183.333. Presentase diperoleh dari hasil pembagian antara total per akun dengan total keseluruhan lalu dikali $100 \%$. 
Tabel 3. Persentase Rincian Kebutuhan UD. AR PUTRA

\begin{tabular}{|l|c|c|c|}
\hline Keterangan & Tahun 2016 & Tahun 2017 & Perbandingan \\
\hline Kertas Mas & $0,290 \%$ & $0,852 \%$ & $0,562 \%$ \\
\hline Kardus & $0,217 \%$ & $0,349 \%$ & $0,132 \%$ \\
\hline Roti & $17,709 \%$ & $17,697 \%$ & $(0,012 \%)$ \\
\hline Coklat Batang & $29,757 \%$ & $35,860 \%$ & $6,103 \%$ \\
\hline Mangkok & $20,322 \%$ & $18,768 \%$ & $(1,554 \%)$ \\
\hline Solasi & $0,362 \%$ & $0,523 \%$ & $0,161 \%$ \\
\hline Label & $0,435 \%$ & $0,582 \%$ & $0,147 \%$ \\
\hline Stiker & $0,145 \%$ & $0,232 \%$ & $0,087 \%$ \\
\hline Plastik & $0,580 \%$ & $0,622 \%$ & $0,042 \%$ \\
\hline Gas & $14,515 \%$ & $12,807 \%$ & $(1,708 \%)$ \\
\hline Gaji Karyawan & $7,257 \%$ & $10,711 \%$ & $3,454 \%$ \\
\hline Listrik & $0,130 \%$ & $0,213 \%$ & $0,083 \%$ \\
\hline Kardus Karton & $1,016 \%$ & $1,047 \%$ & $0,031 \%$ \\
\hline
\end{tabular}

Sumber: UD. AR PUTRA tahun 2018

Berdasarkan tabel di atas diketahui rincian kebutuhan dari tahun 2016 ke 2017 mengalami peningkatan dan penurunan, biaya kertas mas meningkat $0,562 \%$, biaya kardus meningkat $0,132 \%$, biaya roti menurun $(0,012 \%)$, biaya coklat batang meningkat $6,103 \%$, biaya mangkok menurun $(1,554 \%)$, biaya solasi meningkat $0,161 \%$, biaya label meningkat $0,147 \%$, biaya stiker meningkat $0,087 \%$, biaya plastik meningkat $0,042 \%$, biaya gas menurun $5,882 \%$, biaya gaji karyawan meningkat $3,454 \%$, biaya listrik meningkat $0,083 \%$, biaya kerdus karton meningkat $0,031 \%$.

Tabel 4. Perbandingan Rincian Penjualan UD. AR PUTRA

\begin{tabular}{|l|c|c|c|}
\hline Keterangan & Tahun 2016 & Tahun 2017 & Perubahan \\
\hline Penjualan & Rp712.878.000 & Rp766.647.000 & Rp53.769.000 \\
\hline Total & Rp712.878.000 & Rp766.647.000 & Rp53.769.000 \\
\hline
\end{tabular}

Sumber: UD. AR PUTRA tahun 2018

Berdasarkan tabel di atas diketahui perbandingan rincian penjualan pada tahun 2016 ke tahun
2017 mengalami peningkatan sebesar Rp 53.769.000. 
Tabel 5. Neraca Saldo Awal UD. AR PUTRA

\begin{tabular}{|c|c|c|c|c|c|}
\hline \multicolumn{6}{|c|}{ "UD. AR PUTRA" } \\
\hline \multicolumn{6}{|c|}{ NERACA SALDO AWAL } \\
\hline \multicolumn{6}{|c|}{ Periode 2017} \\
\hline No. Akun & Nama Akun & & Debit & & Kredit \\
\hline 100 & Kas & $\mathrm{Rp}$ & 4.956 .400 & & \\
\hline 101 & Kas di Bank & $\mathrm{Rp}$ & 67.541 .200 & & \\
\hline 102 & Piutang Dagang & $\mathrm{Rp}$ & 12.500 .000 & & \\
\hline 103 & Cadangan Kerugian Piutang & & & $\mathrm{Rp}$ & 225.000 \\
\hline 104 & Persediaan Barang Dagang & $\mathrm{Rp}$ & 34.840 .000 & & \\
\hline 109 & Peralatan & $\mathrm{Rp}$ & 13.010 .000 & & \\
\hline 110 & Akumulasi Penyusutan Peralatan & & & $\mathrm{Rp}$ & 2.675 .000 \\
\hline 111 & Gedung & $\mathrm{Rp}$ & 425.000 .000 & & \\
\hline 112 & Akumulasi Penyusutan Gedung & & & $\mathrm{Rp}$ & 57.550 .000 \\
\hline 200 & Utang Dagang & & & $\mathrm{Rp}$ & 13.000 .000 \\
\hline 300 & Modal Sari & & & $\mathrm{Rp}$ & 360.826 .400 \\
\hline 301 & Prive Sari & $\mathrm{Rp}$ & 2.000 .000 & & \\
\hline 400 & Penjualan & & & $\mathrm{Rp}$ & 726.700 .000 \\
\hline 401 & Retur penjualan & $\mathrm{Rp}$ & 10.000 & & \\
\hline 402 & Potongan Penjualan & $\mathrm{Rp}$ & 83.000 & & \\
\hline 500 & Pembelian & $\mathrm{Rp}$ & 513.000 .000 & & \\
\hline 501 & Retur pembelian & & & $\mathrm{Rp}$ & 12.000 \\
\hline 502 & Potongan Pembelian & & & $\mathrm{Rp}$ & 37.200 \\
\hline 600 & Beban Kerugian Piutang Dagang & $\mathrm{Rp}$ & 50.000 & & \\
\hline 601 & Beban Perlengkapan & $\mathrm{Rp}$ & 800.000 & & \\
\hline 602 & Beban Sewa Toko & $\mathrm{Rp}$ & 4.200 .000 & & \\
\hline 603 & Beban Iklan & $R p$ & 6.500 .000 & & \\
\hline 604 & Beban Asuransi & $\mathrm{Rp}$ & 400.000 & & \\
\hline 607 & Beban Gaji & $\mathrm{Rp}$ & 64.900 .000 & & \\
\hline 608 & Beban Air, Listrik \& Telepon & $\mathrm{Rp}$ & 11.300 .000 & & \\
\hline 609 & Beban Umum Lain-lain & $\mathrm{Rp}$ & 435.000 & & \\
\hline 610 & Beban Umum Penjualan & $\mathrm{Rp}$ & 500.000 & & \\
\hline 700 & Pendapatan Bunga & & & $\mathrm{Rp}$ & 1.000 .000 \\
\hline & jumlah & $\mathbf{R p}$ & 1.162 .025 .600 & $\mathbf{R p}$ & 1.162 .025 .600 \\
\hline
\end{tabular}

Sumber: UD AR PUTRA tahun 2018 
Tabel 6. Laporan Laba Rugi UD. AR PUTRA Tahun 2017

\begin{tabular}{|c|c|c|c|c|}
\hline \multicolumn{5}{|c|}{ "UD. AR PUTRA" } \\
\hline \multicolumn{5}{|c|}{ LAPORAN LABARUGI } \\
\hline \multicolumn{5}{|c|}{ PER 31 DESEMBER 2017} \\
\hline Penjualan & & & $\mathrm{Rp}$ & 766.950 .000 \\
\hline Retur Penjualan & $\mathrm{Rp}$ & 160.000 & & \\
\hline \multirow[t]{2}{*}{ Potongan Penjualan } & $\mathrm{Rp}$ & 143.000 & & \\
\hline & & & $\mathrm{Rp}$ & $(303.000)$ \\
\hline Penjualan Bersih & & & $\mathbf{R p}$ & 766.647 .000 \\
\hline Pembelian & $\mathrm{Rp}$ & 513.000 .000 & & \\
\hline Retur Pembelian & $\mathrm{Rp}$ & 222.000 & & \\
\hline Potongan Pembelian & $\mathrm{Rp}$ & 68.200 & & \\
\hline Pembelian Bersih & & & $\mathrm{Rp}$ & $(512.709 .800)$ \\
\hline Beban Pokok Penjualan & & & $\mathrm{Rp}$ & $(31.951 .200)$ \\
\hline Laba Bruto & & & $\mathbf{R p}$ & 221.986 .000 \\
\hline \multicolumn{5}{|l|}{ Bean Operasi: } \\
\hline Beban Kerugian Piutang Dagang & $\mathrm{Rp}$ & 50.000 & & \\
\hline Beban Perlengkapan & $\mathrm{Rp}$ & 800.000 & & \\
\hline Beban Sewa Toko & $\mathrm{Rp}$ & 600.000 & & \\
\hline Beban Iklan & $\mathrm{Rp}$ & 83.333 & & \\
\hline Beban Asuransi & $\mathrm{Rp}$ & 220.000 & & \\
\hline Beban Gaji & $\mathrm{Rp}$ & 71.200 .000 & & \\
\hline Beban Air, Listrik \& Telepon & $\mathrm{Rp}$ & 12.000 .000 & & \\
\hline Beban Umum Lain-lain & $\mathrm{Rp}$ & 435.000 & & \\
\hline Beban Umum Penjualan & $\mathrm{Rp}$ & 500.000 & & \\
\hline Total Beban Operasi & & & $\mathbf{R p}$ & $(85.888 .333)$ \\
\hline \multicolumn{5}{|l|}{ Pendapatan Lain-lain: } \\
\hline Pendapatan Bunga & & & $\mathrm{Rp}$ & 1.000 .000 \\
\hline \multicolumn{3}{|c|}{ Laba Bersih } & $\mathbf{R p}$ & 137.097.667 \\
\hline
\end{tabular}

Sumber: UD AR PUTRA tahun 2018 
Tabel 7. Laporan Perubahan Modal UD. AR PUTRA Tahun 2017

\begin{tabular}{|c|c|c|c|c|}
\hline \multicolumn{5}{|c|}{ "UD.AR.PUTRA" } \\
\hline \multicolumn{5}{|c|}{ LAPORAN PERUBAHAN MODAL } \\
\hline \multicolumn{5}{|c|}{ PER 31 DESEMBER 2017} \\
\hline Modal Awal & & & $\mathrm{Rp}$ & 360.826 .400 \\
\hline Laba Bersih & $\mathrm{Rp}$ & 137.097 .667 & & \\
\hline Prive & $\mathrm{Rp}$ & 2.000 .000 & & \\
\hline Kenaikan Modal & & & $\mathrm{Rp}$ & 135.097 .667 \\
\hline \multicolumn{3}{|c|}{ Modal Akhir } & Rp & 495.924.067 \\
\hline
\end{tabular}

Sumber: UD. AR PUTRA tahun 2018

Tabel 8. Laporan Posisi Keuangan UD. AR PUTRA Tahun 2017

\begin{tabular}{|c|c|c|c|c|c|c|}
\hline \multicolumn{7}{|c|}{ UD.AR PUTRA" } \\
\hline \multicolumn{7}{|c|}{ LAPORAN POSISI KEUANGAN } \\
\hline \multicolumn{7}{|c|}{ PER 31 DESEMBER 2017} \\
\hline Aset & & & & Kewajiban & & \\
\hline Aset Lancar: & & & & Utang Dagang & Rp $\quad 13.000 .000$ & \\
\hline Kas & $\mathrm{Rp}$ & 2.627 .400 & & \begin{tabular}{|l|l} 
Utang Gaji \\
\end{tabular} & $\begin{array}{|ll|}\mathrm{Rp} & 6.300 .000 \\
\end{array}$ & \\
\hline Kas di Bank & $\mathrm{Rp}$ & 106.506 .200 & & Utang Air, Listrik \& Telepon & 700.000 & \\
\hline Piutang Dagang & $\mathrm{Rp}$ & 12.350 .000 & & & & \\
\hline Cadangan Kerugian Piutang & $\mathrm{Rp}$ & $(225.000)$ & & & & \\
\hline Persediaan Barang Dagang & $\mathrm{Rp}$ & 6.133 .800 & & & & \\
\hline Perlengkapan & $\mathrm{Rp}$ & 550.000 & & & & \\
\hline Sewa Dibayar Dimuka & $\mathrm{Rp}$ & 3.600 .000 & & & & \\
\hline Iklan Dibayar Dimuka & $\mathrm{Rp}$ & 6.416 .667 & & & & \\
\hline Asuransi Dibayar Dimuka & $\mathrm{Rp}$ & 180.000 & & & & \\
\hline Total Aset Lancar & & & $\begin{array}{ll}\mathrm{Rp} & 138.139 .067 \\
\end{array}$ & Total Kewajiban & & 20.000 .000 \\
\hline Aset Tetap: & & & & Modal Akhir & & Rp $\quad 495.924 .067$ \\
\hline Peralatan & $\mathrm{Rp}$ & 13.010 .000 & & & & \\
\hline Akumulasi Penyusutan Peralat: & $\mathrm{Rp}$ & $(2.675 .000)$ & & & & \\
\hline \begin{tabular}{|l|l} 
Gedung \\
\end{tabular} & $\mathrm{Rp}$ & 425.000 .000 & & & & \\
\hline Akumulasi Penyusutan Gedung & $\mathrm{Rp}$ & $(57.550 .000)$ & & & & \\
\hline Total Aset Tetap & & & Rp $\quad 377.785 .000$ & & & \\
\hline Aset & & & $\mathrm{Rp} \quad 515.924 .067$ & Kewajiban + M & Modal & Rp $\quad 515.924 .067$ \\
\hline
\end{tabular}

Sumber: UD. AR PUTRA tahun 2018 
Tabel 8. Catatan Atas Laporan Keuangan UD AR PUTRA Tahun 2017

\section{UD. AR PUTRA \\ Catatan Atas Laporan Keuangan}

1. UMUM

UD. AR PUTRA adalah usaha mikro kecil menengah yang bergerak di bidang manufaktur yang memproduksi coklat yang terletak di Dsn. Payak, Ds. Tanon, Kec. Papar - Kediri. UD. AR PUTRA didirikan pada tahun 2013 oleh Bapak Edi Prastowo.

2. IKHTISAR KEBIJAKAN AKUNTANSI

a. Pernyataan Kepatuhan

Laporan keuangan ini disusun sesuai dengan Standar Akuntansi Keuangan (SAK). Kebijakan akuntansi yang dipakai telah sesuai dengan kebijakan yang dipakai untuk menyusun laporan keuangan sebagaimana dijelaskan dibawah ini.

b. Dasar pengukuran dan penyusunan laporan keuangan. Dasar pengukuran laporan keuangan yaitu berdasarkan nilai standar akuntansi yang berlaku. Dasar penyusunan laporan keuangan yaitu dasar akrual kecuali untuk laporan arus kas.

c. Mata uang pelaporan yang digunakan rupiah.

d. Kas dan setara kas terdiri dari kas bank.

e. Persediaan menggunakan metode fifo.

3. ASET KEUANGAN

Aset keuangan diklasifikasikan dalam kelompok berikut:

Aset keuangan yang diukur pada nilai wajar melalui laporan laba rugi. Aset keuangan yang yang diukur pada nilai wajar melaui laporan laba rugi adalah aset keuangan yang ditujukan untuk diperdagangkan.

\section{KESIMPULAN DAN SARAN}

\subsection{Kesimpulan}

Konsep dasar akuntansi merupakan berbagai konsep yang dapat dijadikan standar dalam menyampaikan laporan keuangan yang rapi dan mudah dipahami. Pembuatan laporan keuangan harus didasarkan pada 2 konsep dasar akuntansi yaitu konsep entitas usaha dan konsep biaya. Konsep biaya menetapkan bahwa harta atau jasa yang diperoleh harus dicatat atas dasar biaya yang sesungguhnya, dan konsep biaya itu sendiri dibagi menjadi 2 yaitu konsep unit pengukuran dan konsep objektivitas. Berdasarkan uraian hasil penelitian maka dapat disimpulkan bahwa konsep objektivitas pada laporan keuangan UD. AR PUTRA adalah sebagai berikut:

1. Setiap transaksi penjualan coklat ditulis pemilik pada nota, biayabiaya yang dikeluarkan setiap 
harinya dicatat dalam buku kas.

Pencatatan transaksi menggunakan single entry dengan hanya mencatat penerimaan dan pengeluaran kas saja.

2. Bentuk penerapan akuntansi pada UD. AR PUTRA masih sangat sederhana dan belum sesuai dengan Standar Akuntansi Keuangan (SAK). Persepsi dan pemahaman pemilik usaha UD. AR PUTRA mengenai Standar Akuntansi Keuangan untuk Entitas Tanpa Akuntabilitas Publik (SAK-ETAP) ternyata masih kurang.

3. Kendala-kendala yang dihadapi oleh UD. AR PUTRA dalam menyusun laporan keuangan yaitu karena kurangnya pengetahuan secara teknis dalam menyusun laporan keuangan, khususnya berbasis SAK-ETAP serta kurangnya kesadaran dan disiplin akan pentingnya laporan keuangan yang lengkap dan sesuai standar. UD. AR. PUTRA.

\subsection{Saran}

1. Bagi Perusahaan

a. UD. AR PUTRA diharapkan dapat memberikan perubahan-perubahan sistem kegiatan pembuatan laporan keuangan periode selanjutnya, caranya antara lain pemilik atau karyawan mengikuti kegiatan pelatihan untuk pembekalan dalam pencatatan laporan keuangan yang sesuai dengan Standar Akuntansi Keuangan (SAK).

b. Setiap transaksi agar dilakukan pencatatan transaksi menggunakan jurnal yang telah dibuat simulasi yang diberikan sehingga mempermudah dalam pembuatan laporan keuangan.

2. Bagi Penelitian Selanjutnya

a. Penelitian yang dilakukan peneliti hanya menggunakan data laporan keuangan, biaya terkait dengan bukti transaksi dalam konsep objektivitas, diharapkan peneliti selanjutnya melakukan penelitian mengenai konsep entitas, konsep biaya dan unit pengukuran .

b. Peneliti melakukan penelitian pada perusahaan yaitu pada UD. AR PUTRA, untuk melakukan penelitian selanjutnya diharapkan melakukan penelitian selain pada perusahaan manufaktur yakni seperti perusahaan dagang, perbankan maupun perusahaan yang sudah di audit 


\section{DAFTAR PUSTAKA}

Alim. 2007. Pengaruh Kompetensi dan Independensi Terhadap Kualitas Audit dengan Etika Auditor sebagai Variabel Moderasi. Simposium Nasional Akuntansi X. Makassar. AUEP-08.

Amirullah, Anwar. 2006. Perbedaan Persepsi Mahasiswa Akuntansi terhadap Etika Penyusunan Laporan Keuangan (Studi Kasus Pada Mahasiswa Akuntansi Tahun 2006). Skripsi. Fakultas Ekonomi Universitas Indonesia.

Arikunto, S. 2010. Prosedur penelitian Suatu Pendekatan Praktik. Edisi Revisi. Rineka Cipta. Jakarta.

Budiawan. 2008. Analisis Faktorfaktor yang Mempengaruhi Penyaluran Kredit Pada BPR (Studi Kasus pada BPR di Wilayah Kerja BI Banjarmasin). Tesis. Program Magister Manajemen Universitas Diponegoro.

Daryanto. 1997. Bahasa Kamus Indonesia Lengkap. Surabaya. Penerbit APOLLO.

Departemen Pendidikan Nasional. 2005. Kamus Besar Bahasa Indonesia. Jakarta : Balai Pustaka.

Faud, Moh. Ramly dan M. Rustan D.M. 2005. Akuntansi Perbankan.

Indrawati, Utami. 2006. Muatan Etika dalam Pengajaran Akuntansi Keuangan dan Dampaknya terhadap Persepsi Etika Mahasiswa (Studi Kasus Pada Mahasiswa Akuntansi Keuangan Menengah 1 Pada Semester Ganjil Tahun 2005/2006). Skripsi. Fakulitas Ekonomi Universitas Mercu.
Mabruri. 2010. Analisis Faktor-faktor yang Mempengaruhi Kualitas Hasil Pemeriksaan Hasil Audit di Lingkungan Pemerintah Daerah. Simposium Nasional Akuntansi XIII. Purwokerto.

Made Pasek, Ni Kadek Sinarwati dan Anantawikrama Tungga. 2014. Persepsi Mahasiswa Akuntansi Terhadap Etika Penyusunan Laporan Keuangan. (Studi Kasus Pada Mahasiswa Akuntansi Program S1 dan Program Diploma 3 Tahun 2014). Skripsi. Universitas Pendidikan Ganesha Singaraja.

Praptiwi. 2017. Analisis Pengendalian Persediaan Bahan Baku Menggunakan Metode Eoq (Economic Order Quantity) Pada Ud. Nurisma. Laporan Tugas Akhir. Prodi Akuntansi. Politeknik Kediri.

Resti Putri Susilawati. 2017. Analisis Kinerja Keuangan Pt. Astra Agro Lestari Tbk Dengan Pendekatan Economic Value Added (EVA). Skripsi. Fakultas Ekonomi Dan Bisnis Islam Institut Agama Islam Negeri Batusangkar.

Sofyan Syafri Harapan. 2011. Analisis Kritis Atas Laporan Keuangan. Rajawali Pers. Jakarta.

Sofyan Syafri Harapan. 2011. Teori Akuntansi. Raja Grafindo Persada. Jakarta.

Sopiah dan Sangadji. 2010. Metodelogi Penelitian Pendekatan Praktis Dalam Penelitian. Andi. Yogyakarta.

Sugiyono. 2010. Metode Penelitian Bisnis (Pendekatan Kuantitatif, Kualitatif, dan $R \& D)$. Alfabeta. Bandung. 